\title{
RESEARCH QUALITY OF THE WHEAT-RYE BREAD WITH ADDITION OF THE POLYFUNCTIONAL FOOD SUPPLEMENT «MAGNETOFOOD»
}

\author{
Iryna Tsykhanovska \\ Department of food and chemical technologies \\ Ukrainian Engineering-Pedagogics Academy \\ 16 Universitetska str., Kharkiv, Ukraine, 61003 \\ cikhanovskaja@rambler.ru \\ Victoria Evlash \\ Department of Chemistry, Microbiology and Food Hygiene \\ Kharkiv State University of Nutrition and Trade \\ 333 Klochkivska str., Kharkiv, Ukraine, 61051 \\ evlashvv@gmail.com \\ Alexandr Alexandrov \\ Department of food and chemical technologies \\ Ukrainian Engineering-Pedagogics Academy \\ 16 Universitetska str., Kharkiv, Ukraine, 61003 \\ alexandrov.a.v.a.v@gmail.com \\ Karina Svidlo \\ Department of Technology and Restaurant Business Organization \\ Kharkiv Trade and Economic Institute of Kyiv National Trade \\ and Economic University of Ukraine \\ 8 O. Yarosha lane, Kharkiv, Ukraine, 61045 \\ karinasvidlo@rambler.ru \\ Tatyana Gontar \\ Department of food and chemical technologies \\ Ukrainian Engineering-Pedagogics Academy \\ 16 Universitetska str., Kharkiv, Ukraine, 61003 \\ taty-gontar@ukr.net
}

\begin{abstract}
The influence of the polyfunctional food additive "Magnetofood" on the yield, batching, shrinkage, as well as physicochemical, microbiological, organoleptic parameters of wheat-rye bread" Kharkiv Rodnichok " enriched with this additive was investigated. The introduction of the food additive "Magnetofood" helps to increase the biological value (the content of the microelement of Fe is increased by $3 \mathrm{mg} / 100 \mathrm{~g}$ ), the energy value (increases by $3 \mathrm{kcal} / 100 \mathrm{~g}$ ) and the storage period (grows by 12 hours) in the experimental bread samples "Kharkiv Rodnichok" compared with the control (wheat-rye bread "Darnitsky"). That is, the food supplement "Magnetofood" due to Fe ${ }^{2+}$ can be recommended as an antioxidant and a source of easily digestible iron and an anti-anemia agent. It has been experimentally established that the introduction of the polyfunctional food additive "Magnetofood" improves the yield and quality of wheat-rye bread. In addition, the quality of bread is influenced by the way of introduction of "Magnetofood": when introducing "Magnetofud" in the form of an oil suspension $(\mathrm{CHI})$, the indices are 1-2\% better than when adding the additive as a dry powder. It also follows from the data obtained that the physicochemical parameters of the experimental bread samples "Kharkiv Rodnichok " are improved in comparison with the control (Bread "Darnitsky") as follows: yield, bake, shrinkage, porosity of crumb are increased by 2-3\%, 5-10 \%, 5-10\%, 3-6 \% respectively; and the crumb humidity and acidity decrease by $1 \%$ and $1.0-1.5^{\circ}$, respectively. Microbiological studies have shown that seeding Bac. subtilis after 10 days will increase: in control 2 times, and in the samples of bread "Kharkov fontanel" 1,2 - in 1,3 times. That is, "Magnetofood" has an antimicrobial effect, which leads to better quality, preservation of freshness and lengthening the shelf life of bakery products. Thus, the introduction of the polyfunctional food additive "Magnetofood" in wheat-rye bread improves yield, quality and shelf life.

Keywords: magneto-food, food additive, wheat-rye bread, quality indicators.
\end{abstract}




\section{Introduction}

The biological value of wheat-rye bread is determined primarily by its digestibility and content of additional nutrition factors in it: mineral elements, essential amino acids, and vitamins. But in addition to enrichment with nutrients, it is necessary to pay attention to such indicators of quality as aroma, appearance, condition of the cuticle. The volume of wheat-rye bread, structural and mechanical properties depend on the gas-forming and the gas-retaining ability of the dough, and these factors depend on the quality of the raw materials used in the preparation of bread.

To date, the quality of raw materials does not always meet the requirements set. Modern bakery enterprises have to solve such tasks as: to increase the output of bakery products, to improve the quality, appearance of products, to enrich the necessary nutrients, to extend the shelf life of the product.

For this purpose, various complex bakery improvers are used. Purposeful application of various nutritional additives can correct and improve the quality of flour and yeast with unstable properties and quality of the finished product [1-3].

In this regard, improving the quality and the composition of bakery products, and in particular wheat-rye bread, by introducing various additive-enhancers is an urgent task for bakery enterprises [4-13]. The positive effect of the use of bakery products enriched with poly-functional food additives is provided either by the incorporation of the necessary additional components into the formulation, or by the exception of unwanted ones, as well as by changing the technology of their preparation.

A polyfunctional food supplement "Magnetofood is used as a nutritional supplement,. This ultrathin powder with a particle size of 30-60 $\mathrm{nm}$, therefore has a developed, active surface; It also has antimicrobial activity, emulsifying ability, good compatibility with proteins, carbohydrates, and also has specific properties: bactericidal, bacteriostatic, antioxidant, complexing, moistureretaining, sorption $[4,5]$. All this complex of characteristics allows us to recommend "Magnetofood" as a polyfunctional food additive in bakery products.

Thus, studies devoted to the development of the technology of production of wheat-rye bread of improved quality with an increased biological value, with an extended shelf-life and using a multifunctional nutritional supplement "Magnetofood" are relevant.

The purpose of the work is to study the influence of the multifunctional nutritional supplement "Magnetofood" on the quality indicators of wheat-rye bread "Kharkiv Rodnichok".

\section{Materials and Methods}

\section{1. Explored materials and equipment used in the experiment}

The study used: - control - wheat-rye bread "Darnytsky" [GOST 26983-2015 and DSTU-P 4583:2006] [14]; - sample 1 - wheat-rye bread "Kharkiv Rodnichok" with 0,15\% "Magnetofood" in the form of powder [4]; - sample 2 - wheat-rye bread "Kharkov spring" from $0,15 \%$ "Magnetofood" in the form of oil-magnetophase suspension (OMM), while the OMS is injected 0,35 wt. \% [5].

In order to introduce a polyfunctional nutritional supplement "Magnetofood" in wheat-rye bread, two methods were used:

1) the food supplement "Magnetofood" was administered in a dry form by kneading the dough in a quantity of $150 \mathrm{~g}$ per $100 \mathrm{~kg}$ of flour;

2) food supplement "Magnetofood" was injected in the form of OMS in the amount of 350 grams per $100 \mathrm{~kg}$ of flour when kneading the dough.

The rational amount of nutritional supplement "Magnetofood" and OMS has been selected experimentally. The optimal ratio in the suspension of "Magnetofood": surfactant (monoacylglycerol $)=15.0$ wt. $\%: 65.0 \mathrm{wt} \%[4,5]$.

OMSs were used to better distribute the multifunctional nutritional supplement "Magnetofood" and to obtain a homogeneous structure of bread. OMS was obtained by mixing heated to $60-70{ }^{\circ} \mathrm{C}$ of oil (sunflower) from 99.0 to $99.25 \%$ by weight heated to $60-70{ }^{\circ} \mathrm{C}$ in a water bath with a suspension of 0.75 to $1.0 \%$ by weight based on "Magnetofood" and Surface active substance (surfactant) - monoacylglycerol Dimodan HP (Danisco, Denmark) (or polyglycerinurici- 
noleates). Optimal ratio in the suspension of "Magnetofood": surfactant (stabilizer)=15.0 mass \%: 65.0 mass $\%[4,5]$.

In Fig. 1, 2 shows experimental samples of wheat-rye bread "Kharkiv Rodnichok" and devices used for researches of qualitative indicators of bread.

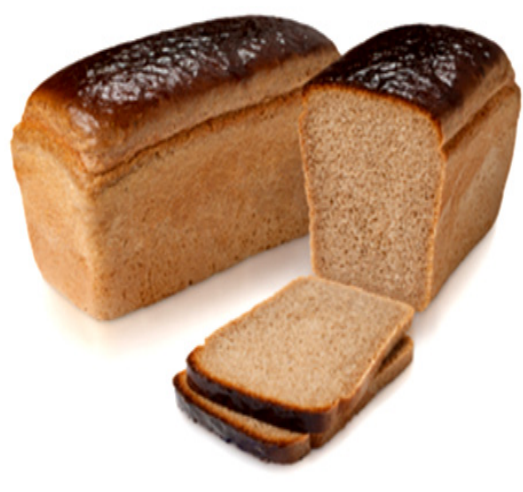

$a$

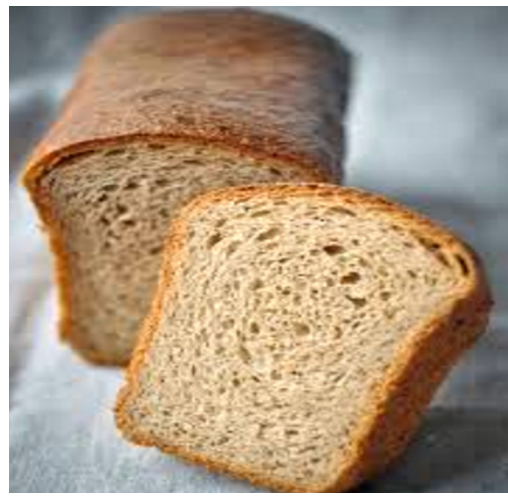

$b$

Fig. 1. Experimental bread samples and a device for determining the specific volume: $a$ - bread "Kharkiv Rodnichok"; $b$ - Darnitsky bread

The specific volume of bread was measured using a RH-BIO volume (Russia); the determination of the porosity of the crumb was carried out on the device Zhuravlev; swelling - on an amylograph (Amylograph "Amylographer-E” company "Brabender” Germany).

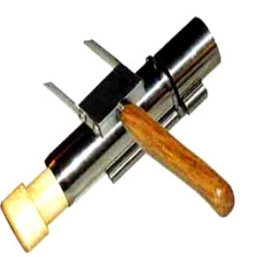

$a$

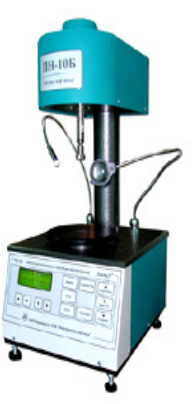

$b$

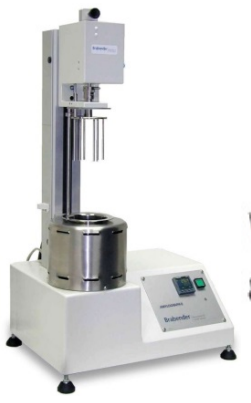

$c$

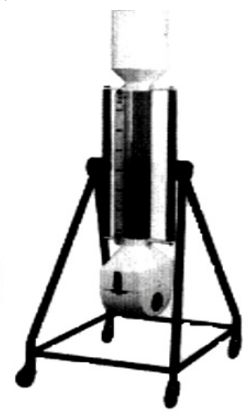

$e$

Fig. 2. Devices used for research of qualitative indicators of bread: $a$-device Zhuravlev; $b$ - penetrometer AP-4/2; $c$ - amylograph-E; $d$-VFH-250; $e$ - volume RZ-BIO

Structural-mechanical properties (elasticity, shrinkage) - on automated penetrometer AP-4/2 (firm "Feynmass" Germany). Sizes of bread were determined on the device VFH-250 (analog Y1-ENX) (Russia).

\section{2. Methods of determination of organoleptic, physico-chemical, structural and microbio- logical parameters}

In the process of performing experimental work, standard research methods were used, discussed further [15-24].

Organoleptic evaluation of wheat-rye bread quality was carried out in accordance with GOST 52961-2008 and DSTU-P 4583:2006. For organoleptic analysis of freshness of bread samples (on a 5-point scale - appearance: shape, condition of the surface, color, the condition of the cuticle: the heat, the product, the porosity, the taste, the smell was established by a close correlation dependence with the values of the modulus of crumb elasticity - correlation coefficient amounted to 0,96 . In this case, the methods of organoleptic and tasting evaluation of bread's freshness were developed at the Moscow Technological Institute of the Food Industry: an alternative organoleptic assessment and a differentiated score on the organoleptic assessment of freshness [23, 24] In the 
alternative assessment of the freshness of bread, 30 tasters took part .The tasting agent gave an estimate of bread, fresh or stale, the number of bread grades, classified as a percentage of the total, was taken as a percentage of freshness or quicksand. on a 5-point scale of the following gradation: very fresh 5 , fresh 4 , moderately stale 3 , stale 2 , very stale 1 [15].In accordance with the requirements of normative and technical documents, the main physical and chemical indicators of the quality of bakery products are: moisture content of the crumb, mass fraction of bound moisture, acidity, porosity, determination of bread yield [15].

Determination of humidity was driven by the standard accelerated method according to GOST 21094-75. The essence of the method is to dry the crushed mildew at a certain temperature and determine the moisture content. The mass fraction of bound moisture was detected by an indicator medote, followed by a determination of the concentration of dry matter on a refractometer (10\% sucrose solution was used as an indicator) $[15,19]$. Determination of the acidity of bakery products was carried out using a titrimetric method in accordance with GOST 5670-96. The method of determining the coefficient of swelling of the cuticle was based on the determination of the hydrophilicity of the colloids of the pulp [15-18]. The swelling (in $\mathrm{ml} / 1 \mathrm{~g}$ of dry matter) was determined on the amylograph "Amylograph-E" from the change in the bound water content by determining the concentration of the indicator (glucose, sucrose) when mixed with bread pulp. The change in concentration occurred due to the difficulty of penetration of the indicator in microness of the bread crumb, filled with water $[17,18]$. The yield of bread (HGP, \%) was determined as the difference in the weight of the initial half-finished product and the finished product according to the method developed by Botasheva G. Yu. [16]. Also, the weight loss in baking was taken into account - dry (\%) and cooling of baked bread - drying $(\%)[15,16]$. Porosity was determined by the standard method [17, 18$]$.

The structural and mechanical properties of bread crumb (elasticity, \%; elastic modulus E, Pa; shrinkage, \%) were determined by measuring its elastic properties on an automated penetrometer AP-4/2. With this instrument, the general deformation of the bread crumb ( $\Delta$ Nobsch), which characterizes its compression, was determined; plastic deformation $\left(\Delta \mathrm{H}_{\text {пл }}\right)$ or elasticity and elastic deformation $\left(\Delta \mathrm{H}_{\text {упр }}\right)$ or shrinkage were determined by methods [15-18]. To characterize the process of bread drawing, a method for determining the elastic modulus E was used, which characterizes the depth of immersion of a cone-shaped penetrometer indenter under load in bread crumb $[17,18]$. Crushing was determined in $\%$ of the formed crumb in relation to the mass of the cake $[15,17]$. The uniformity of wheat-rye bread was determined by the formula: F=N/P ( $\mathrm{H}-$ height, $\mathrm{cm}, \mathrm{P}$ - perimeter, $\mathrm{cm}$ ); the specific volume $\left(\mathrm{Vp} . \mathrm{cm}^{3} / \mathrm{g}\right)$, which was determined by dividing the bread volume by its mass, was expressed to an accuracy of $0.01 \mathrm{~cm}^{3} / \mathrm{g}$, while the bread volume in $\mathrm{cm}^{3}$ was measured using the $\mathrm{RH}$ device - BIO, which operates on the principle of measuring the volume of bulk filler pressed with bread (the bread volume was measured three times) [15-18].

The list of microbiological indicators, which were used to control the quality of the finished bakery products, was established in accordance with the requirements of the Chipboard 4.4.5.078 and the MBT No. 5061-89: the number of mesophilic aerobic and optional anaerobic microorganisms (KMAFAnM, KUO/g); the presence of bacteria in the group of intestinal sticks (BGKP (coliform), in $0,001 \mathrm{~g}$ ); detection of gold staphylococci, protein and other pathogenic microorganisms (pathogenic microorganisms, including bacteria of the genus Salmonella, $25 \mathrm{~g}$ ) [20-22]. To determine the bactericidal threshold of the action of the food additive "Magnetofood" in relation to spore bacteria, bacteria were added to the flour in the amount of 1.103 spores/g of flour. After baking, the products were incubated in provocative conditions (humidity $80-85 \%$, temperature $15-25{ }^{\circ} \mathrm{C}$ ) for three days and determined the number of CFU (colony-forming units) of Bac. subtilis in a sample of a cushion by sowing on MPA (meat-peptone agar) and incubation at $+40{ }^{\circ} \mathrm{C}$ within one day. The study of the influence of the multifunctional nutritional supplement "Magnetofood" on the quality of wheat and rye bread "Darnytsky" and "Kharkiv Rodnichok" during storage was carried out on prototype samples (control, sample 1 and sample 2 - see section 2.1.). As the basic formulation in the research, the formula for wheat-rye bread "Darnytsky" [GOST 26983-2015 and DSTU-P 4583:2006] was chosen (Table 1). Baking was carried out at a temperature of $180-200{ }^{\circ} \mathrm{C}$ for a further 3 to 5 minutes [JU 15.8-37-00032744-004:2005]. 
Table 1

Recipe for experimental samples of wheat-rye bread "Kharkiv Rodnichok" with food additive "Magnetofood" and wheat-rye bread "Darnitsky" (control))

\begin{tabular}{|c|c|c|c|}
\hline \multirow[t]{2}{*}{ Ingredients of wheat-rye bread } & \multirow{2}{*}{$\begin{array}{c}\text { Bread } \\
\text { "Darnitsky" } \\
\text { Control }\end{array}$} & $\begin{array}{l}\text { Bread "Kharkov spring } \\
\text { In the form of powder }\end{array}$ & $\begin{array}{l}\text { " with a food additive "Magnetofood" }(0,15 \%) \\
\text { In the form of a suspension (OMS }-0.35 \%)\end{array}$ \\
\hline & & Sample 1 & Sample 2 \\
\hline Weight of one loofah, $\mathrm{kg}$ & 0,7 & 0,7 & 0,7 \\
\hline Composition of the product (per $100 \mathrm{~kg}$ ): & - & - & - \\
\hline Wheat flour of the first brand, $\mathrm{kg}$ & 80 & 80 & 80 \\
\hline Flour rye rumble, $\mathrm{kg}$ & 20 & 20 & 20 \\
\hline Yeast pressed, $\mathrm{kg}$ & 1,0 & 1,0 & 1,0 \\
\hline Salt, kg & 1,5 & 1,5 & 1,5 \\
\hline Magnetofood, $\mathrm{kg}$ & - & 0,15 & - \\
\hline OMS, kg & - & - & 0,35 \\
\hline
\end{tabular}

Experimental samples of bread were stored at a temperature of $(20 \pm 2){ }^{\circ} \mathrm{C}$ and relative humidity (75 \pm 2$) \%$, and in regimes corresponding to the necessary storage conditions [JUU 15.8-3700032744-004:2005]. The evaluation of bread quality indicators was carried out in several stages: immediately, as well as after 6, 12, 24, 36, 48, 60, 72, 84 hours after baking.

Table 2 shows the chemical composition, nutritional value and shelf-life of experimental samples of wheat-rye bread "Darnytsky" and "Kharkiv Rodnichok".

Table 2

Chemical composition, nutritional value and shelf-life of experimental samples of wheat-rye bread "Kharkiv Rodnichok" in comparison with control

\begin{tabular}{ccccccc}
\hline $\begin{array}{c}\text { Experienced } \\
\text { samples of bread }\end{array}$ & \multicolumn{4}{c}{ Chemical composition, g/100 g of the product } & Caloric content, & Shelf life, year \\
& Squirrels & Fat & Carbohydrates & Microelement, mg:Fe & $\begin{array}{c}\text { kcal/100 g (kJ/100 g) } \\
\text { Control }\end{array}$ \\
Sample 1 & 7,4 & 0,9 & 47,0 & - & $216,0(904,0)$ & 72 \\
Sample 2 & 7,4 & 0,9 & 47,0 & 3,0 & $216,0(904,0)$ & 84 \\
\end{tabular}

Data Table 2 shows an increase in the content of the trace element Fe ( $3 \mathrm{mg} / 100 \mathrm{~g})$, the energy value ( $3 \mathrm{kcal} / 100 \mathrm{~g})$, and the shelf life (12 hours) in the experimental samples of bread "Kharkiv Rodnichok" in comparison with the control. It should be noted that the biological value (Fe content) and the shelf life of wheat-rye bread are the same in samples of 1,2 and calories higher in sample 2. That is, the introduction of a nutritional supplement "Magnetofood" in the form of an oily suspension (OMS) increases the caloric content of the finished product on $1.4 \%$ in comparison with the control and with sample 1, where "Magnetofood" was introduced as a powder.

\section{3. Experimental procedures}

Fig. 3 shows the influence of the food additive "Magnetofood" on the organoleptic parameters of the experimental samples of bread "Kharkiv Rodnichok" in comparison with the control (on a five-point scale). 


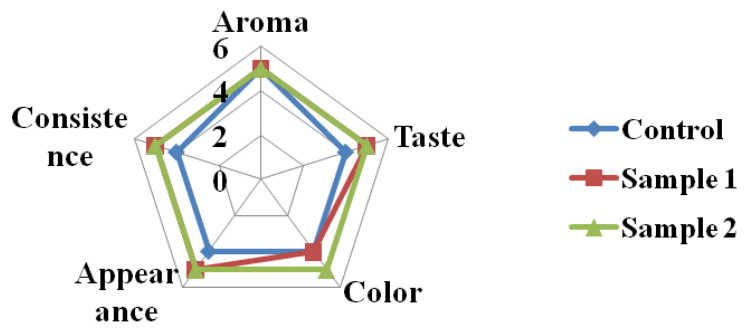

Fig. 3. Influence of food additive "Magnetofood" on organoleptic parameters of experimental samples of bread "Kharkiv Rodnichok"in comparison with control

The physical and chemical parameters were determined to verify the correctness of the technological process of obtaining wheat-rye bread and the evaluation of its quality: the mass fraction of the moisture of the crumb, the yield, the dry matter, the dryness, the acidity, the porosity of bread. An important indicator of the bread quality is acidity, which characterizes its freshness and taste. Bread with low acidity persists longer. It should be noted that the level of acidity of wheat-rye bread "Kharkiv relatives" with a nutritional supplement "Magnetofood" is lower compared with the control (Table 3). The mass fraction of the moisture of the crumb - this indicator is closely linked to the quality and stability of bread during storage, since excess moisture promotes the flow of enzymatic and chemical reactions, activates the activity of microorganisms, including those that lead to damage of bread, in particular its mold. Experimental data on the determination of this indicator are in Fig. 4. Another important indicator of the bread quality is porosity. The porosity of bread indicates the ratio of the volume of pores to the total volume of bread crumb and expressed as a percentage. The porosity of bread is due to its digestibility. Well-loosened bread with even fine, thin-walled porosity is better permeated with digestive juices and is therefore more fully digested. Apparently, the dependence of porosity of experimental samples of wheat-rye bread on the addition of a poly functional nutritional supplement "Magnetofood" is presented in Fig. 4. The results of physical and chemical research of samples of wheatrye bread are shown in Fig. 4

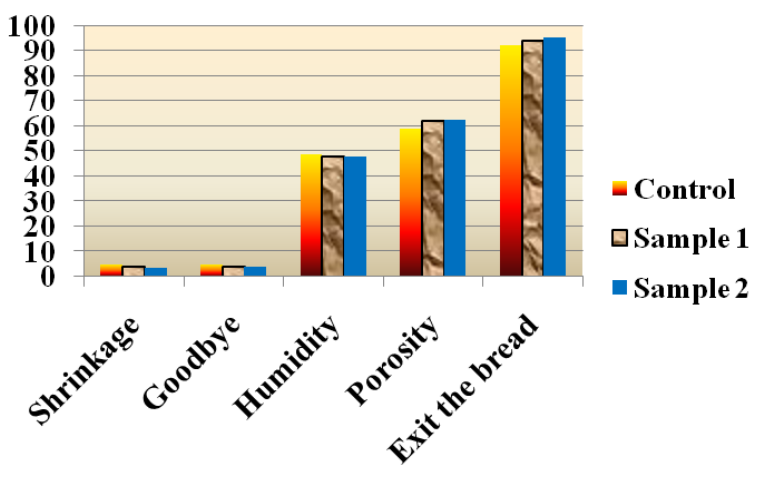

Fig. 4. Influence of nutritional supplement "Magnetofood" on physical and chemical parameters of bread samples "Kharkiv Rodnichok"in comparison with control

The analysis of experimental data in Fig. 4 shows that the introduction of a poly-functional food supplement "Magnetofood" improves the yield and quality of wheat-rye bread in all of the considered indicators. In addition, the qualitative characteristics of bread also influences the way of introduction of "Magnetofood": when the introduction of "Magnetofood" in the form of OMS, indicators are by $1-2 \%$ better than when adding the additive in the form of dry powder.

Table 3 shows the experimental data of the influence of the nutritional supplement "Magnetofood" on the acidity and contamination of the spores of bacteria Bac. subtilis, which cause "potato disease", experimental samples of wheat-rye bread. 
Table 3

Influence of the food additive "Magnetofood" on the acidity and contamination of the spores of bacteria Bac. subtilis experimental samples of wheat-rye bread

\begin{tabular}{ccccc}
\hline Name of indicators & Standard & Control & Samples of wheat-rye bread \\
& & 8,0 & 8,0 & 7,0 \\
Sample 2 \\
\hline $\begin{array}{c}\text { The acidity of the crumb, hail, is not bigger } \\
\begin{array}{c}\text { The number of bacterial spores Bac. subtilis } \\
\text { CFU / g, bucket / after 10 days }\end{array}\end{array}$ & $0,4 \times 10^{3}$ & $0,20 \times 10^{3} / 0,40 \times 10^{3}$ & $0,15 \times 10^{3} / 0,20 \times 10^{3}$ & $0,13 \times 10^{3} / 0,17 \times 10^{3}$
\end{tabular}

The obtained data confirm the antimicrobial action of the food additive «Magnetofood» and its ability to reduce the acidity of the bread crumbs.

\section{Results}

Data Table 2 shows on the experimental samples of wheat-rye bread "Kharkiv Rodnichok" with a nutritional supplement "Magnetofood" that the storage period of the finished product increases by 12 hours in comparison with the control, its biological and energy value increases.

From the experimental data of Fig. 3 it is evident that more qualitative samples of wheatrye bread are obtained at the addition of a nutritional supplement "Magnetofood". Moreover, the method of introduction of "Magnetofod" affects only the color. The colors get worse when you add an OMS supplement.

From the data of Fig. 4 and Table 3 we can see that the physicochemical parameters of bread samples " Kharkiv Rodnichok " are improved in comparison with the control as follows: output, dry, dry, porosity of the pulp increases by $2-3 \%, 5-10 \%, 5-10 \%, 3-6 \%$ respectively; and the moisture content of the crumb and acidity is reduced by $1 \%$ and $1.0-1.5$ respectively. Table 3 shows that the number of spores of bacteria Bac. subtilis after 10 days increases: in control 2 times, and in samples $1,2-$ in 1,3 times.

\section{Conclusions}

It has been experimentally proved that the introduction of a multifunctional nutritional supplement "Magnetofood" improves the yield and quality of wheat-rye bread, namely

- increases:

- output 2-3\%;

- dump on $5-10 \%$;

- drying up by $5-10 \%$;

- porosity of the pulp on 3-6\%;

- decreases;

- moisture content of the crumb by $1 \%$;

- acidity by $1,0-1,5$;

- contamination of bacterial spores Bac. subtilis after 10 days increases: in control 2 times, and in samples 1,2 - in 1,3 times. That is, the food additive "Magnetofood" has the antimicrobial effect and promotes the quality and shelf life of wheat-rye bread. In addition, the qualitative characteristics of the bread also influences the way of introduction of "Magnetofood": when the introduction of "Magnetofood" in the form of OMS indicators of 1-2\% is better than when adding the additive in the form of dry powder. Thus, the results of the conducted studies can justify the expediency of using the multifunctional nutritional supplement "Magnetofood" in the technology of wheat-rye bread.

\section{References}

[1] Matveeva, I. V., Belyavskaya, I. G. (2003). Pishchevye dobavki i hlebopekarnye uluchshiteli v proizvodstve muchnyh izdeliy. Moscow: MGUPP, 115.

[2] Modich, P. (2000). Produkty CARGILLFOODS dlya khlebopekov. Pishchevaya promyshlennost', 2, 52-53. 
[3] Vasil'eva, O. L., Asmanova, Z. I., Mikhaylova, E. O. (1991). Pishchevye dobavki v khlebobulochnykh izdeliyakh. Khleboprodukty, 1, 34-38.

[4] Iliuha, N., Barsova, Z., Tsykhanovska, I., Kovalenko, V. (2010). Tehnologiia proizvodstva i pokazateli kachestva pishchevoi dobavki na osnove magnetita. Eastern-European Journal Of Enterprise Technologies, 6 (10 (48)), 32-35. Available at: http://journals.uran.ua/eejet/article/view/5847

[5] Tsykhanovska, I. V., Demydov, I. M., Barsova, Z. V., Pavlotska, L. F. (2015). Doslidzhennia protsesiv okysniuvalnykh ta termichnykh peretvorenn v systemi: oliino-lipido-mahnetytova suspenziia. Prohresyvna tekhnika ta tekhnolohii kharchovykh vyrobnytstv restorannoho hospodarstva i torhivli, 1 (21), 353-362.

[6] Evlash, V. V., Pohozhykh, N. Y., Kadnykova, N. H. (2006). Protyvoanemycheskaia pyshchevaia dobavka «Hemovytal» v tekhnologii pshenychno-rzhanoho khleba. Khlibopekarska i kondyterska promyslovist Ukrainy, 2 (15), 9-11.

[7] Evlash, V. V., Niemirich, O. V., Vinnikova, V. O. (2008). Tekhnolohiia khliba zhytno-pshenychnoho, shcho zbahachenyi na hemove zalizo, ta otsinka yakosti (pochatok). Khlebopekarskoe i kondyterskoe delo, 1 (16), 48-51.

[8] Evlash, V. V., Niemirich, O. V., Vinnikova, V. O. (2008). Tekhnolohiia khliba zhytno-pshenychnoho, shcho zbahachenyi na hemove zalizo, ta otsinka yakosti (zakinchennia). Khlebopekarskoe i kondyterskoe delo, 2 (16), 48-50.

[9] Evlash, V. V., Kruhlova, O. A., Vinnikova, V. O. (2008). Khlib «Badorist» yak funktsionalnyi produkt kharchuvannia ta yoho konkurentospromozhnist. Obladnannia ta tekhnolohii kharchovykh vyrobnytstv, 18, 37-43.

[10] Evlash, V. V., Pohozhykh, M. I., Niemirich, O. V., Vinnikova, V. O. (2007). Pat. No. 26696 UA. Sposib vyrobnytstva prianykiv "Badorist”. MPK A21D 13/08. No. u200700379; declareted: 15.01.2007; published: 10.10.2007, Bul. No. 16, 5.

[11] Martins, Z. E., Pinho, O., Ferreira, I. M. P. L. V. O. (2017). Food industry by-products used as functional ingredients of bakery products. Trends in Food Science \& Technology, 67, 106-128. doi: 10.1016/ j.tifs.2017.07.003

[12] Lai, W. T., Khong, N. M. H., Lim, S. S., Hee, Y. Y., Sim, B. I., Lau, K. Y., Lai, O. M. (2017). A review: Modified agricultural by-products for the development and fortification of food products and nutraceuticals. Trends in Food Science \& Technology, 59, 148-160. doi: 10.1016/j.tifs.2016.11.014

[13] Dziki, D., Rozylo, R., Gawlik-Dziki, U., Swieca, M. (2014). Current trends in the enhancement of antioxidant activity of wheat bread by the addition of plant materials rich in phenolic compounds. Trends in Food Science \& Technology, 40 (1), 48-61. doi: 10.1016/j.tifs.2014.07.010

[14] Drobot, V. I. (2002). Tekhnolohiia khlibopekarskoho vyrobnytstva. Kyiv: Lohos, 552.

[15] Koryachkina, S. Ya., Berezina, N. A., Khmeleva, E. V. (2010). Metody issledovaniya kachestva khlebobulochnykh izdeliy. Orel: OrelGTU, 166.

[16] Botasheva, G. Yu. (2013). Tekhnologiya virobnitstva khlibobulochnikh virobiv. Cherkessk: BITS SevKavGGTA, 43.

[17] Kasymova, Ch. K. (2012). Laboratornyy praktikum po kursu «Tekhnologiya khleba, konditerskikh i makaronnykh izdeliy». Bishkek: Kyrgyzskiy gosudarstvennyy tekhnicheskiy universitet im. I. Razzakova, 48.

[18] Romanov, A. S., Davydenko, N. I., Shatnyuk, L. N. et. al. (2005). Ekspertiza khleba i khlebobulochnykh izdeliy, kachestvo i bezopasnost. Novosibirsk: Sib. univ. iz-vo, 278.

[19] Yurchak, V. G., Berzina, N. I., Shmarovoz, V. M., Prishchepa, M. P. (1989). Opredelenie svyazannoy vody indikatornym metodom v khlebopekarnom proizvodstve. Izvestiya Vuzov. Pishchevaya tekhnologiya, 4, 78-80.

[20] Mikrobiolohichni normatyvy ta metody kontroliu produktsii hromadskoho kharchuvannia (2001). DSP 4.4.5.078., zatv. MOZ Ukrainy 7.11.2001 r. Kyiv: MOZ Ukrainy, 17.

[21] Mediko-biologicheskie trebovaniya i sanitarnye normy kachestva prodovol'stvennogo syr'ya i pishchevykh produktov No. 5061 (1990). Moscow: Izd-vo standartov, 186.

[22] Produkty pishchevye. Metod opredeleniya kolichestva mezofil'nykh aerobnykh i fakul'tativno-anaerobnykh mikroorganizmov (1996). GOST 104444.15; vved. 01.01.97. Kyiv: Gosstandart Ukrainy, 16.

[23] Kalinina, I. V., Naumenko, N. V., Feklicheva, I. V. (2015). Issledovanie kachestva obogashchennykh vidov khleba v protsesse khraneniya. Vestnik YUUrGU. Seriya «Pishchevye i biotekhnologii», 3 (1), $36-44$.

[24] Goryacheva, A. F., Kuz'minskiy, R. V. (1983). Sokhranenie svezhesti khleba. Moscow: Legkaya i pishchevaya promyshlennost', 240 . 